\title{
Pengembangan Unit Penangkar Bibit Lada Berkualitas Di Politeknik Negeri Lampung
}

\author{
Bambang Utoyo ${ }^{1}$, Adryade Reshi Gusta ${ }^{1}$, Yan Sukmawan*1, Made Same ${ }^{1}$ \\ \#Jurusan Budidaya Tanaman Perkebunan, Politeknik Negeri Lampung \\ Jl, Soekarno-Hatta No. 10 Rajabasa, Bandar Lampung \\ ${ }^{1}$ ysukmawan@polinela.ac.id
}

\begin{abstract}
Pepper is one of the spice crops that contribute to improving the Indonesian economy. Pepper cultivation is carried out on a small scale to a large scale. Pepper propagation by cutting is considered quite effective and efficient. Politeknik Negeri Lampung has been develop the Pepper Nursery Unit since 2007. This unit runs a business in the production of climbing pepper seedling, shrub pepper seedling, and pepper nursery training. The aim of this program is to support the mission of Politeknik Negeri Lampung in preparing itself to face college campus autonomy through the acquisition of revenue from established business units, accelerating the process of developing an entrepreneurial cultural system in the campus environment, providing competency development opportunities for staff and students, and increasing the role of the Politeknik Negeri Lampung for the community, especially in agriculture. The impact of this program is the availability of hight quality pepper seedling, increasing income generating Politeknik Negeri Lampung, establishment of the Pepper Nursery Unit and training service, improving the skills of Politeknik Negeri Lampung students in pepper nursery, developing entrepreneurial potential for students and staff, as well as increasing the role of Lampung State Polytechnic in community service activities.
\end{abstract}

Keywords-Campus entrepreuneurship, estate crop, nursery business.

\section{PENDAHULUAN}

Lada (Piper nigrum Linn.) merupakan tanaman rempahrempah yang memiliki peran penting dalam meningkatkan perekonomian Indonesia (Martin et al., 2015). Budidaya lada di Indonesia dilakukan dalam skala kecil hingga besar (Rukmana, 2003). Beberapa sentra produksi lada adalah Bangka Belitung, Lampung, Kalimantan Timur, Sumatera Selatan, Sulawesi Selatan (Yuhono, 2007; Kemala, 2015).

Metode perbanyakan vegetatif tanaman lada dengan cara setek dinilai efektif dan efisien. Perbanyakan lada dengan setek lebih menguntungkan karena menghasilkan populasi tanaman yang homogen dan memiliki sifat yang sama dengan induknya. Bahan tanam yang digunakan untuk setek lada dapat berasal dari cabang sulur panjat dan cabang buah (Pranowo \& Syafarudin, 2011; Suparman et al., 2017).

Salah satu kendala dalam perbanyakan tanaman dengan setek yaitu sulitnya mendapatkan bahan tanaman dalam jumlah yang banyak dan berkualitas. Harga bibit lada yang mahal merupakan salah satu faktor sulitnya mendapatkan bahan tanaman dalam jumlah banyak dan berkualitas. Belum adanya penangkar bibit lada di Lampung adalah salah satu kendala banyaknya bibit-bibit lada perdu yang ditanam oleh petani yang tidak jelas asal induknya (illegitim). Belum lagi serangan penyakit busuk pangkal batang yang disebabkan oleh jamur Phytopthora yang menurunkan produksi tanaman lada. Kedua hal ini menyebabkan rendahnya produksi lada dan menjadi permasalahan yang berkepanjangan dengan dampak yang sangat merugikan bagi petani di masa yang akan datang. Produktivitas kebun lada rakyat di Lampung masih tergolong rendah yaitu rata-rata $591 \mathrm{~kg} / \mathrm{ha}$, dibandingkan dengan produktivitas nasional yang mencapai $800 \mathrm{~kg} / \mathrm{ha}$.

Melihat kendala yang dihadapi oleh petani yang akan berkebun lada untuk mendapatkan bibit yang berkualitas, Politeknik Negeri Lampung mencoba membantu petani yaitu dengan membentuk Unit Penangkar Bibit Lada Berkualitas (UPBLB). Penggunaan teknologi oleh unit penangkar bibit lada berkualitas antara lain menggunakan bibit varietas unggul yang bersertifikasi dan penggunaan agen hayati Trichoderma. Mekanisme cendawan ini bersifat antagonis (Ismail dan Tenrirawe, 2013). Hasil penelitian yang dilakukan oleh Manohara et al. (2005) dan Wahyuno (2015) menunjukkan bahwa cendawan Trichoderma harzianum mampu menekan intensitas serangan $P$. infestans (penyebab penyakit busuk pangkal batang lada) sebesar 50\%. UPBLB Politeknik Negeri Lampung diharapkan dapat menjadi model inkubator bisnis bagi staf dan mahasiswa di lingkungan Politeknik Negeri Lampung. Selain itu, UPBLB Politeknik Negeri Lampung juga melakukan pelatihan dan pembinaan bagi mahasiswa, alumni, siswa SMK/SMA, dan petani yang tertarik mengembangkan wirausaha pembibitan dan budidaya lada

Tujuan dari program UPBLB ini yaitu 1) mempercepat proses pengembangan sistem budaya kewirausahaan di lingkungan Kampus Politeknik Negeri Lampung, 2) memberikan kesempatan pengembangan kompetensi kepada dosen, karyawan, dan mahasiswa yang mempunyai 
kreativitas, 3) pemanfaatan hasil penelitian yang telah dilakukan untuk mengembangkan produksi bibit lada berkualitas sehingga dapat bermanfaat secara langsung bagi masyarakat, dan 4) menumbuhkan budaya penelitian terapan di perguruan tinggi yang dapat diakses dan dipraktikkan oleh masyarakat

\section{TARGET DAN LUARAN}

Target pada tahun pertama difokuskan pada:

- Produksi bibit lada unggul sebanyak 20.000 bibit. Bibit yang dikembangkan berasal dari varietas Natar 1 yang toleran terhadap penyakit busuk pangkal batang (BPB) sehingga mempunyai tingkat pertumbuhan dan produksi yang tinggi.

- Penanaman kebun induk lada yang akan digunakan sebagai sumber bahan tanam.

- Kegiatan lain pada tahun pertama adalah memperbaiki sistem irigasi yang sudah rusak, melengkapi sarana penyimpanan bahan dan alat (gudang), penambahan tangki air sebagai cadangan air. Peningkatan kebutuhan bibit lada oleh masyarakat di Provinsi Lampung dan sekitarnya memacu untuk dikembangkannya usaha pembibitan tanaman lada di Polinela.

Luaran unit PPUPIK ini yang utama adalah tercapainya pengembangan Unit Pembibitan Lada Berkualitas dengan produk unggulan berupa bibit lada dan jasa layanan pembibitan lada berkualitas baik untuk pihak dalam kampus maupun pihak luar. Selanjutnya, sejalan dengan pertumbuhan dan perkembangan luas areal tanaman lada pada tahun-tahun berikutnya diharapkan dapat terbentuk sentra produksi dan pengembangan bibit lada berkualitas dan tercipta wahana pendidikan dan pelatihan bagi dunia pendidikan, penelitian, dan masyarakat umum.

\section{METODE PELAKSANAAN}

Kegiatan PPUPIK UPBLB ini dilaksanakan di Kebun Pembibitan Politeknik Negeri Lampung sejak Januari 2018. Aktivitas yang dilakukan pada tahun pertama adalah perbaikan bangunan pembibitan lada serta penambahan sarana dan prasarana produksi. Bangunan pembibitan lada pada awalnya masih menggunakan bambu sebagai rangka naungan (Gambar 1).
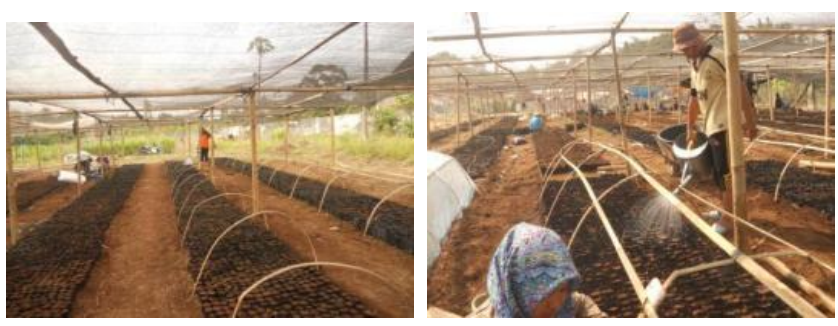
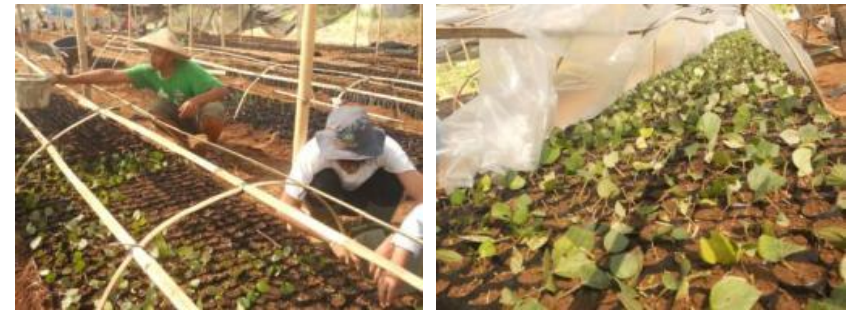

Gambar 1. Bibit lada di lokasi pembibitan Politeknik Negeri Lampung

\section{A. Produksi Bibit Lada Berkualitas}

Kegiatan pembibitan lada diawali dengan pembuatan bangunan pembibitan lada semi permanen menggunakan rangka baja ringan yang dilengkapi dengan naungan dari paranet. Bahan tanam lada varietas Natar 1 yang digunakan berasal dari penangkaran bibit lada di Lampung Timur. Bahan tanam lada berupa setek satu ruas berdaun tunggal disemai pada polibeg yang disusun dalam bedenganbedengan berukuran $1,2 \mathrm{~m}$ x $20 \mathrm{~m}$. Untuk mempercepat pertumbuhan akar diberikan zat pengatur tumbuh auksin dan setek direndam dalam larutan fungisida untuk mencegah kebusukan pada setek. Untuk mengurangi penguapan, bedeng semai disungkup dengan plastik transparan. Satu setengah bulan setelah penyemaian, sungkup plastik dibuka dan bibit lada diberi Trichoderma dengan cara dibenamkan dalam media tanam. Bibit dipelihara di bangunan pembibitan sampai dengan siap untuk disalurkan.

\section{B. Pelayanan dan Jasa}

UPBLB selain menajalankan aktivitas produksi barang berupa bibit lada, juga menjalankan aktivitas pelayanan dan jasa bagi mahasiswa atau staf Politeknik Negeri Lampung. Siswa SMK/SMA dapat melakukan kegiatan magang berkaitan dengan pembibitan lada dan petani dapat melakukan kunjungan atau mengikuti pelatihan tentang teknik pembibitan lada berkualitas. Selain itu, UPLB juga melayani kunjungan agroekoedukasi bagi siswa sekolah TK sampai dengan SMP

\section{HASil Dan PeMBahasan}

Beberapa kegiatan penelitian dari tahun 2010 sampai dengan 2016 tentang budidaya lada di kebun pembibitan lada yang dilakukan oleh dosen di Politeknik Negeri Lampung antara lain: pemanfaatan bokashi dan kompos kiambang (pupuk organik) sebagai campuran media pembibitan, penggunaan inokulum mikoriza di pembibitan lada, penggunaan cendawan antagonis Trichoderma di pembibitan lada, cara dan dosis pupuk di tanaman lada, dan penggunaan tajar/lanjaran pada tanaman lada. Beberapa hasil penelitian tersebut telah diaplikasikan dalam kegiatan produksi bibit lada dan juga diaplikasikan ke dalam praktik mahasiswa pada mata kuliah seperti Produksi Tanaman Perkebunan. Hasil penerapan praktik mahasiswa, setek lada dapat dibedakan menjadi setek panjang (setek 5-7 ruas) dan setek pendek (setek satu ruas). Setek 5-7 ruas dapat 
langsung ditanam di lapangan, tetapi kekurangannya memerlukan bahan tanam yang banyak. Sedangkan setek satu ruas memiliki kelebihan dapat menghasilkan bahan tanam yang banyak, tetapi kekurangannya memerlukan bedengan pembibitan. Dari hasil penelitian dan juga penerapan praktik mahasiswa di lapangan, selanjutnya teknologi-teknologi tersebut diterapkan untuk pengembangan unit penangkar bibit lada dalam program PPUPIK

Sebelumnya sudah berjalan kerja sama untuk produksi bibit lada setek satu ruas dengan Dinas Perkebunan Kabupaten Way Kanan pada tahun 2015. Kerjasama ini untuk keperluan produksi lada untuk skala lokal, tetapi keberadaannya sangat membantu petani lada di Lampung. Selain itu juga disampaikan bagaimana cara melakukan pembibitan lada yang baik dan benar serta budidaya lada. Masyarakat petani sangat antusias mengikuti kegiatan tersebut. Sejak tahun 2015 sampai dengan tahun 2016 ini bibit yang telah disalurkan ke petani mencapai 40.000 bibit di Kabupaten Way Kanan di Provinsi Lampung.

TABEL I

JUMLAH DAN BIBIT YANG TELAH DIPRODUKSI TAHUN 2015 S.D. 2016

\begin{tabular}{|c|c|c|}
\hline Tahun & Jumlah Bibit & Lokasi Penanaman \\
\hline 2015 & 32.000 & Way Kanan \\
\hline 2016 & 8.000 & Way Kanan \\
\hline
\end{tabular}

Kegiatan UPBLB yang telah dijalankan sangat menunjang kegiatan akademik, dimana mahasiswa dapat mengikuti kegiatan produksi bibit lada dari mulai persiapan lahan sampai dengan bibit siap salur. Dampak dari adanya Unit Penangkar ini adalah menambah income generating Politeknik Negeri Lampung dan menumbuhkan jiwa wirausaha bagi mahasiswa. Petani di daerah Lampung dapat lebih mudah mendapatkan bibit lada berkualitas sehingga akan meningkatkan pendapatan petani. Selain itu, program ini juga dapat meningkatkan kompetensi mahasiswa dalam bidang pembibitan lada, dan sebagai tempat magang dan kunjungan siswa.

\section{A. Produksi}

Kegiatan produksi bibit lada saat ini telah dilakukan dengan menggunakan fasilitas yang tersedia di lapangan, areal pembibitan, instalasi pengairan, saung/ gudang, rumah naungan, dan sumur pompa di Politeknik Negeri Lampung (Gambar 2).
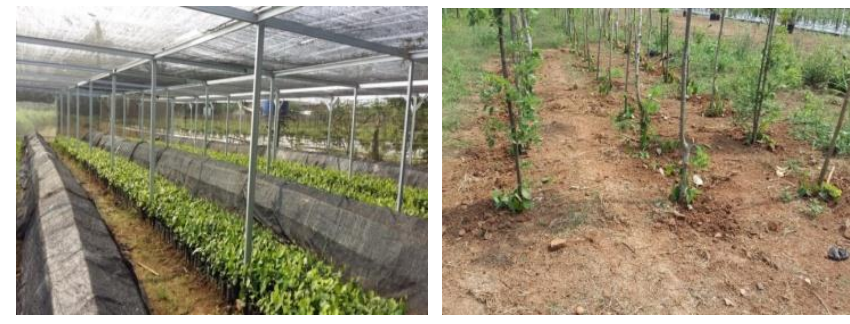

Gambar 2. Perbaikan bangunan pembibitan lada dan penanaman kebun induk lada

Pada tahun pertama, produksi bibit lada dilakukan dengan memproduksi bibit lada panjat sebanyak 20.000 bibit dan bibit lada perdu dalam polybag sebanyak 1.000 bibit, dan tanaman lada perdu dalam pot sebanyak 100 tanaman. Pemilihan jenis produk ini didasarkan pada target market, yaitu petani lada, sedangkan jasa pelatihan dan pembinaan ditujukan bagi masyarakat umum, dosen, karyawan, mahasiswa, dan alumni BUMN yang ingin usaha perkebunan lada. Jasa pendampingan dan pelatihan ditujukan pada para petani lada, UPR-UPR yang baru memulai usahanya. Pelayanan jasa kunjungan agroekoedukasi ditujukan bagi siswa TK, SD, dan SMP yang ingin mengetahui dan belajar mengenai pembibitan dan budidaya tanaman lada. Proses bisnis pada UPBLB Politeknik Negeri Lampung disajikan pada Gambar 3.

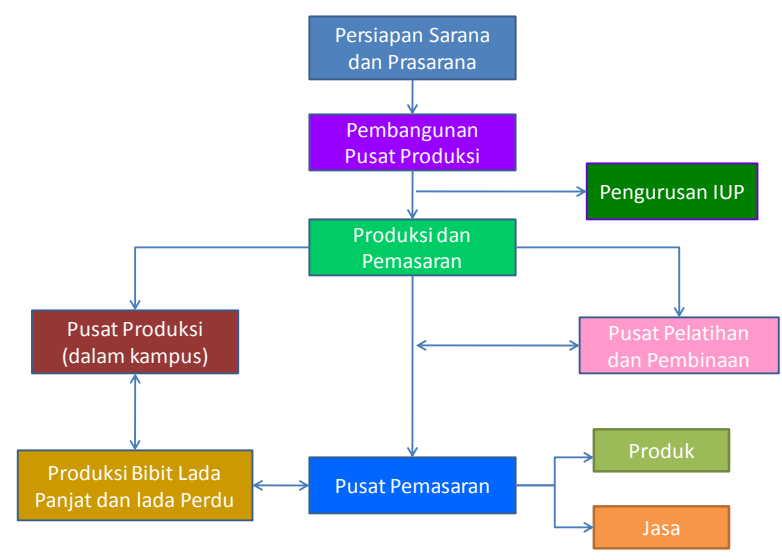

Gambar 3. Bagan alir proses bisnis pada Unit Penangkar Bibit Lada Berkualitas Politeknik Negeri Lampung

Persiapan Setek Lada

Setek lada diambil dari sulur panjat yang sudah berkayu berasal dari pohon induk varietas unggul berumur $<3$ tahun (belum berproduksi), sehat, tanpa gejala serangan hama dan penyakit, lalu dicuci dengan air mengalir. Untuk memperbanyak lada dapat menggunakan setek 1 ruas.

Cara membuat setek 1 ruas yaitu:

- Penggunaan setek satu ruas berdaun tunggal harus disemaikan terlebih dahulu pada polibeg sampai tumbuh menjadi 5-7 ruas. 
- Setek panjang dipotong-potong menjadi setek satu ruas berdaun tunggal.

- Setek direndam dalam larutan gula (1-2\%) selama 1/2 - 1 jam, lalu disemai dalam polibeg ukuran $10 \times 12 \mathrm{~cm}$ yang berisi media tanam campuran tanah atas (top soil) dengan pupuk kandang dan pasir kasar atau sekam padi dengan perbandingan 2:1:1 atau 1:1:1

- Setek yang sudah ditanam dalam polibeg disimpan ditempat persemaian yang ternaungi (intensitas sinar matahari 50-75\%).

- Naungan persemaian dapat terbuat dari daun kelapa, alang-alang atau paranet.

- Persyaratan persemaian dapat dilihat pada Format-1 dan harus mengikuti Standarisasi Nasional Indonesia (SNI) 2006 dari Badan Standardisasi Nasional (BSN).

- Untuk mempertahankan kelembaban lingkungan, maka diperlukan sungkup plastik dengan kerangka bambu setinggi lebih kurang $1 \mathrm{~m}$. Penyiraman dilakukan 2 hari sekali dengan menggunakan selang (manual). Sungkup dibuka setiap pagi (jam 09.00-10.00) selama 1 jam.

- Apabila telah tumbuh 2-3 daun baru, setiap benih harus diberi tegakan dari bambu agar terbentuk akar lekat. Sungkup plastik kemudian dibuka. Benih siap ditanam apabila setek telah tumbuh mencapai 5-7 ruas

\section{Pemeliharaan Bibit dalam Polibeg}

Pemeliharaan bibit di polibeg meliputi penyiraman, pengendalian gulma, pemupukan, dan seleksi bibit. Penyiraman dapat dilakukan dengan sistem sprinkler atau cara manual dua kali sehari jika tidak turun hujan. Pengendalian gulma di dalam dan di luar polibeg dilakukan setiap bulan secara manual untuk di dalam polibeg dan secara kimia/mekanis di luar polibeg. Pemupukan dilakukan dengan cara membenamkan pupuk NPK sesuai dosis anjuran setiap dua minggu sekali. Pengendalian hama dan penyakit dilakukan jika tampak ada gejala serangan HPT. Seleksi bibit di polibeg dilakukan pada saat bibit berumur 3 bulan yang memiliki 2-3 ruas. Bibit yang berkualitas saja yang disalurkan, yaitu bibit yang pertumbuhannya baik, tumbuh normal dan tidak terserang hama dan penyakit.

\section{Sertifikasi bibit}

Sertifikasi bibit oleh Balai Pengawasan dan Pengujian Mutu Benih (BP2MB) Dinas Perkebunan dilakukan sebelum bibit disalurkan dengan cara mengajukan permohonan kepada Kepala Dinas Perkebunan Provinsi c.q. Kepala UPTD BP2MB. Permohonan akan ditindaklanjuti dengan pemeriksaan lapangan dan penerbitan sertifikat sertifikasi dan pembuatan label sertifikat. Proses sertifikasi bibit lada saat ini sedang dalam proses. Bibit akan disalurkan setelah dikeluarkannya sertifikat dan label bibit.

\section{B. Manajemen}

Dalam menentukan rencana produksi secara realistis diperlukan beberapa pertimbangan (asumsi) sebagai berikut :
1. Pelaksanaan proses produksi bibit lada pada tahun pertama sebanyak 10.000 bibit lada.

2. Bersamaan dengan produksi bibit lada dapat dilakukan pelatihan, pembinaan, dan kunjungan bagi yang memerlukan dalam satu tahun 2-6 kali.

3. Rekrutmen tenaga kerja dan pengembangan struktur organisasi dilakukan sesuai kebutuhan dan perkembangan usaha.

4. Evaluasi dan standardisasi produk, proses, system manajemen, dan pemasaran dilaksanakan secara periodik 6 bulan sekali.

5. Sistem keuangan, perpajakan, inventarisasi, dan auditing akan dilakukan secara transparan menganut sistem yang ada.

Peningkatan kapasitas hanya dapat dilakukan dengan penambahan sarana dan prasarana produksi. Investasi pertama, kedua, dan ketiga yang telah dilakukan dan keuntungannya akan direinvestasikan untuk pengembangan usaha dengan pengadaan sarana prasarana sehingga pada tahun keempat usaha mandiri.

\section{Pemasaran}

\section{Sasaran pemasaran}

Pemasaran dilakukan ke segmen pasar petani lada di Lampung (Way Kanan, Lampung Utara, Tanggamus, dan Lampung Timur). Seiring dengan pengembangan kapasitas produksi, selanjutnya hingga Sumatera Selatan.

\section{Produk dan harga jual}

Struktur harga yang akan dibentuk sesuai harga pasar yang berlaku pada saat pemasaran dilakukan. Struktur harga yang direncanakan ini, memperhatikan segmentasi pasar yang berhubungan dengan jumlah produk yang akan dibeli. Harga jual bibit lada siap salur adalah sebesar Rp8.500,00 per polibeg.

\section{Strategi pemasaran}

Dalam rangka mendekatkan produk kepada konsumen maka akan dilakukan promosi, direncanakan akan dilakukan pemasangan iklan baris di koran, menyebarkan leaflet ke masyarakat, pemasangan spanduk di depan kampus serta melakukan kerjasama dengan gabungan kelompok tani (Gapoktan) di Lampung. Selain itu, dilakukan promosi ke sekolah dalam pemasaran jasa kunjungan bagi siswa (kunjungan agroekoedukasi).

\section{Sistem Pemasaran}

Pemasaran produk akan dilakukan secara langsung ditempat produksi maupun melalui kerjasama dengan Gapoktan di wilayah Provinsi Lampung.

\section{KESIMPULAN}

Kegiatan Unit Penangkar Bibit Lada Berkualitas yang dilakukan sangat menunjang kegiatan akademik, dimana mahasiswa dapat mengikuti kegiatan produksi bibit lada dari mulai persiapan lahan sampai dengan bibit siap salur. Dampak dari adanya Unit Penangkar ini adalah menambah income generating Politeknik Negeri Lampung, menumbuhkan jiwa wirausaha bagi mahasiswa, petani 
daerah Lampung dengan mudah mendapatkan bibit lada berkualitas sehingga akan meningkatkan pendapatan petani, meningkatkan kompetensi mahasiswa dalam bidang pembibitan lada, dan sebagai tempat magang dan kunjungan siswa.

\section{UCAPAN TERIMA KASIH}

Tulisan ini merupakan bagian dari program pengabdian masyarakat melalui hibah multi tahun Program Pengembangan Usaha Produk Intelektual Kampus (PPUPIK) yang didanai oleh Kementerian Riset, Teknologi, dan Pendidikan Tinggi.

\section{DAFTAR PUSTAKA}

[1] Ismail, N. and Tenrirawe, A., 2013. Potensi agen hayati Trichoderma sp. sebagai agens pengendali hayati. Seminar Regional Inovasi Teknologi Pertanian, Mendukung Program Pembangunan Pertanian Provinsi Sulawesi Utara. Balai Pengkajian Teknologi Pertanian (BPTP) Sulawesi Utara, pp: 177-189

[2] Kemala, S., 2015. Strategi pengembangan sistem agribisnis lada untuk meningkatkan pendapatan petani. Perspektif, 6(1), pp. 47-54.

[3] Manohara, D., Wahyuno, D., and Noveriza, R., 2005. Penyakit busuk pangkal batang tanaman lada dan strategi pengendaliannya. Perkembangan Teknologi Tanaman Rempah dan Obat, 17(2), pp. 41-57.

[4] Martin, A.B., Same, M. and Indrawati, W., 2015). Pengaruh media pembibitan pada pertumbuhan setek lada (Piper nigrum L.). Jurnal Agro Industri Perkebunan, 3(2), pp. 94-107.

[5] Pranowo, D., and Syafaruddin, S., 2011. Organic Fertilizer as A Substitute of Anorganic Fertilizer Toward Organic Pepper Shurbs. Jurnal Tanaman Industri dan Penyegar, 2(3), pp. 285-290.

[6] Rukmana, R., 2003. Usaha Tani Lada Perdu. Kanisius, Yogyakarta.

[7] Suparman, U., Sopandi, A., and Burhan, A., 2017. Beberapa keuntungan penggunaan bibit lada asal setek satu ruas. Buletin Penelitian Tanaman Rempah dan Obat, 7(1), pp. 5-9.

[8] Wahyuno, D., 2015. Pengendalian terpadu busuk pangkal batang lada. Perspektif, 8(1), pp. 17-29.

[9] Yuhono, J.T., 2007. Sistem agribisnis lada dan strategi pengembangannya. Jurnal Litbang Pertanian, 26(2), pp. 76-81. 